\title{
An update of the sediment fluxes investigation in the Rio Cordon (Italy) after $\mathbf{2 5}$ years of monitoring
}

\author{
Lorenzo Picco, ${ }^{1}$ Luca Mao, ${ }^{2}$ Emanuel Rigon, ${ }^{1}$ Johnny Moretto, ${ }^{1}$ Diego Ravazzolo, ${ }^{1}$ \\ Fabio Delai, ${ }^{1}$ Mario Aristide Lenzi ${ }^{1}$ \\ ${ }^{1}$ Department of Land, Environment, Agriculture and Forestry, University of Padova - AGRIPOLIS, \\ Legnaro, PD, Italy; ${ }^{2}$ Department of Ecosystems and Environment, Pontificia Universidad Católica \\ de Chile, Santiago, Chile
}

\begin{abstract}
Quantification of bed-load transport in high-gradient mountain streams is important, but the field data needed to test transport models are scarce and difficult to obtain. In the present study, we describe the experimental station for monitoring water and sediment fluxes built in 1985 on the Rio Cordon, a small step-pool channel in the eastern Italian Alps. The measuring station consists of an inclined frame that separates fine from coarse sediments $(\mathrm{D}>20 \mathrm{~mm})$, which are continuously measured by a series of ultrasonic sensors fitted above a storage area. The acquired 25 -year dataset, which comprises a high-magnitude/low-recurrence flood event, has allowed a magnitude-frequency analysis of bed-load volumes to be performed. Results from a combined frequency analysis of peak water discharge and total bed-load volumes are presented. In addition, the integration between the sediment
\end{abstract}

Correspondence: Mario Aristide Lenzi, Department of Land, Environment, Agriculture and Forestry, University of Padova - AGRIPOLIS, 35020 Legnaro (PD), Italy.

Tel. +39.049 .8272675 - Fax: +39.049 .8272686 .

E-mail: marioaristide.lenzi@unipd.it

Key words: alpine torrents, bed load, magnitude-frequency analysis, sediment supply, water and sediment fluxes.

Acknowledgements: our thanks to the ARPAV-VENETO REGION, the Arabba Avalanche Center, in particular Mr. Walter Testor, for providing maintenance information at the Rio Cordon station. Part of this research was founded by both the Strategic Project of the University of Padua GEORISKS-Geological, morphological, hydrological processes: monitoring, modeling and impact in the North-Eastern Italy, Research Unit 3, Department of Land and Agro-forest Environments, STPD08RWBY-004, and the SedAlp Project: sediment management in Alpine basins, integrating sediment continuum, risk mitigation and hydropower, 83-4-3-AT, in the framework of the European Territorial Cooperation Program Alpine Space 2007-2013.

Received for publication: 26 July 2012.

Accepted for publication: 3 November 2012.

(C) Copyright L. Picco et al., 2012

Licensee PAGEPress, Italy

Journal of Agricultural Engineering 2012; XLIII:e17

doi:10.4081/jae.2012.e17

This article is distributed under the terms of the Creative Commons Attribution Noncommercial License (by-nc 3.0) which permits any noncommercial use, distribution, and reproduction in any medium, provided the original author(s) and source are credited. transport dataset and the repeated surveys of sediment sources and of channel changes allowed us to assess the geomorphological effectiveness of different flood events. Despite the importance of the experimental station for making these bed-load observations possible, its maintenance costs are not low and these may have an impact on its future existence. At the same time, improving current instrumentation and future installations with novel technology would make the station an ideal location for calibrating surrogate techniques for sediment transport monitoring.

\section{Introduction}

Sediment transport in steep mountain streams can occur as bedload or debris flows, depending on basin geomorphological and sediment supply conditions (Bathurst et al., 2003, 2010; Bischetti and Chiaradia, 2010; Fattorelli et al., 1988; Lenzi, 2006; Lenzi et al., 1990, 1999, 2003a, 2006, 2011; Mao and Lenzi, 2007; Mao et al., 2005, 2008, 2009; Rigon et al., 2012). The quantification of bed-load transport in steep mountain streams is of major importance for planning hazard mitigation, predicting reservoir sedimentation, and understanding the morphodynamics of higher-order channels (Powell et al., 2000; Andreoli et al., 2005; Niedda and Greppi, 2010; Nitsche et al., 2011; Yager et al., 2012). However, poorly sorted mountain rivers may require infrequent high discharges for the mobilization of the coarsest clast size. Therefore, only a portion of finer (gravel and cobble) particles is likely to be entrained annually (Wohl, 2000; Lenzi, 2004; Yager et al., 2012). The monitoring activity of bed-load transport in small, steep $\left(<10 \mathrm{~km}^{2}\right)$ mountain catchments poses problems that are very complex due to the impulsive or high-energy nature of this process, where intense sediment transport can even lead to non-Newtonian flows, such as hyper-concentrated flows or debris flood (Di Stefano et al., 2007; Mintegui et al., 2010; Lenzi et al., 2011).

The short duration and relatively low frequency of occurrence of the events require the implementation of robust and reliable systems for performing direct field observation. Indeed, monitoring activities carried out through permanently installed devices are very costly. However, these experimental sites become extremely valuable when long-term series of data are eventually produced, thus allowing statistically significant analysis and experience-based predictions (Mao et al., 2008; Nitsche et al., 2011; Yager et al., 2012). Experimental measuring stations thus represent precious tools for the scientific community, as well as for the agencies dealing with torrent control and land use planning (Di Stefano et al., 2007). This paper presents the experimental facility of the Rio Cordon (Eastern Italian Alps), summarizes the results gained during 25 year of operations, and discusses the costs and drawbacks of the technology used. 


\section{Materials and methods}

\section{Study basin and measuring station}

The Rio Cordon is a boulder-bed, step-pool stream draining an area of $5 \mathrm{~km}^{2}$. Due to its high elevation and past use for cattle grazing, forests cover only the lower part of the catchment (7\% of the area). Alpine grasslands dominate (61\%), followed by shrubs (18\%) and bare land (14\%). The bedrock mainly consists of dolomites, volcaniclastic conglomerates and tuff sandstones. Quaternary deposits are also very common. The Rio Cordon mean channel slope is $13.6 \%$ and the longitudinal channel profile displays an alternation of high-gradient and low-gradient stretches. Some reaches of the Rio Cordon channel feature step-pool morphology. Table 1 shows the main watershed characteristics (Lenzi et al., 2004). The average bed surface grain size distribution is characterized by $\mathrm{d}_{16}=37 \mathrm{~mm}, \mathrm{~d}_{50}=119 \mathrm{~mm}$ and $\mathrm{d}_{84}=357 \mathrm{~mm}$ (Lenzi et al., 2004). Through detailed field surveys of the longitudinal profile carried out before and after floods of different magnitudes, Lenzi (2001) demonstrated that the step-pool sequences are bed structures that fail only during low-frequency intense flood events. In the Rio Cordon, active sediment sources, represented by bare slopes, shallow landslides, eroded stream banks and minor debris flow channels, cover approximately $5 \%$ of the basin area. However, approximately $50 \%$ of the total sediment source area is located upstream of a low gradient belt where sediment deposition takes place, thus making sediment supply from the upper part of the basin to be of minor relevance (Dalla Fontana and Marchi, 2003; Lenzi et al., 2004). The generally limited sediment availability within the main channel can occasionally be increased either during low-frequency events that are able to remove the bed armor layer (as during the 1994 flood) or by minor mud and debris flows entering the main channel from the steeper tributaries (Lenzi et al., 2004).

A station for monitoring water discharge, suspended sediment and bed-load transport has been operating since 1986 in the Rio Cordon. Measurements are taken by separating coarse grains (minimum size $20 \mathrm{~mm}$ ) from water and fine sediments (Lenzi et al., 1999, 2004). The measuring station consists of an inlet flume, an inclined grid where the separation of coarse particles takes place, a storage area for coarse sediment deposition, and an outlet flume to return water and fine sediment to the stream (Figure 1). The volume of bedload is measured at 5 min intervals by 24 ultrasonic sensors fitted on a fixed frame over the storage area (Lenzi et al., 1999, 2004). Suspended sediment is measured by two turbidimeters: a Partech SDM-10 (Partech s.r.l., Parma, Italy) light absorption and a Hach SS6 light-scatter instrument (Hach Company, Loveland, C0, USA) (Lenzi and Marchi, 2000). Flow and suspended sediment samples are gathered automatically using a Sigma pumping sampler (Hach Company) installed at a fixed position in the inlet channel. Overall, 24 bed-load events (Table 2) characterized by bed-load transport (grain size greater than $20 \mathrm{~mm}$ ) were recorded by the Rio Cordon station from 1986 to 2006 (Lenzi et al., 2004; Mao and Lenzi, 2007; Mao et al., 2008). Liquid discharge is measured at three positions in the experimental station using pressure transducers and water level gauges. A complete weather station operates at the experimental site (1763 m a.s.l.) measuring precipitation, snow accumulation, air temperature, relative humidity, and solar radiation. A further complete meteorological station is located on the upper part of the basin at $2130 \mathrm{~m}$ a.s.l. (Mondeval di Sora station).

On $14^{\text {th }}$ September 1994 , an intense flood featuring a peak water discharge of $10.4 \mathrm{~m}^{3} \mathrm{~s}^{-1}$ and a peak bed-load transport rate of approximately $157 \mathrm{~kg} \mathrm{~s}^{-1}\left(25 \mathrm{~kg} \mathrm{~s}^{-1} \mathrm{~m}^{-1}\right)$ was recorded (Lenzi et al., 2004). Such a high-magnitude event features the typical flash flood pattern i.e., a very high peak flow rate, a very short duration $(4 \mathrm{~h})$, and $900 \mathrm{~m}^{3}$ as total bedload volume. The coarsest boulders (approx. $1 \mathrm{~m}$ ) of the bed surface were entrained and transported to the station. Most sediment was sup- plied by the channel bed after the bed armor layer was removed, and channel banks, plus some point sources on the catchment slopes (Lenzi et al., 2004). Such a high-magnitude, low-frequency event has represented a geomorphological threshold for the Rio Cordon basin, since it has altered the stream bed geometry (Lenzi, 2001) and the sediment supply characteristics of the basin as a whole (Lenzi et al., 2004). Comparing the bed-load/flow rate relationship and the ratio between bed-load volume and effective runoff for all floods, Lenzi et al. (2004) demonstrated the increase in sediment availability and the consequent

Table 1. Main characteristics of the Rio Cordon basin and channel (Lenzi et al., 2004).

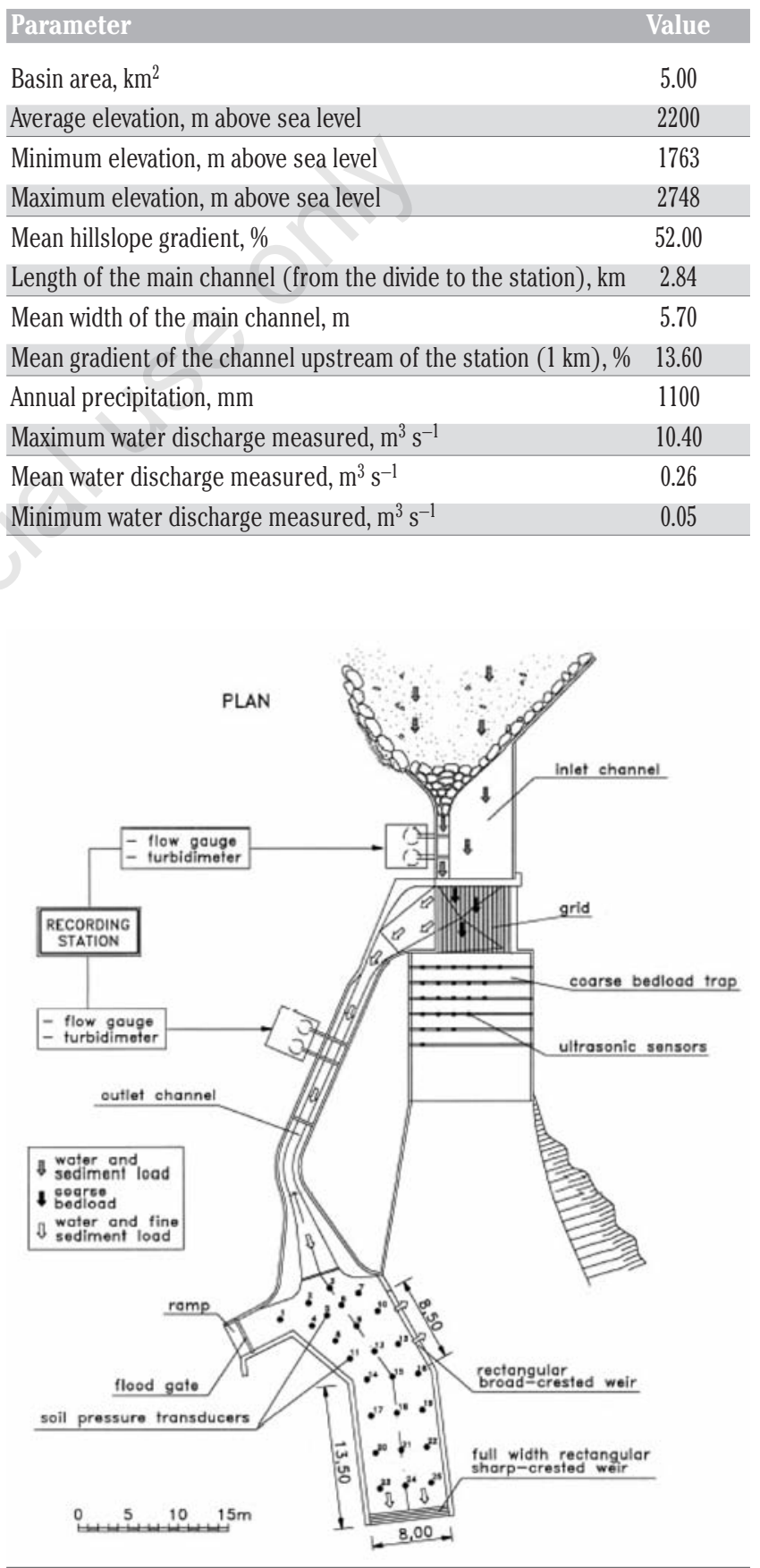

Figure 1. Plan of the Rio Cordon bedload measuring station (after Lenzi et al., 2004). 
increase in bed-load transport after the 1994 low-frequency event. During ordinary flood events, bedload showed intensities of up to $30 \mathrm{~kg}$ $\mathrm{s}^{-1}\left(4.6 \mathrm{~kg} \mathrm{~s}^{-1} \mathrm{~m}^{-1}\right)$, but most bed-load rates ranged from 0.1 to $3 \mathrm{~kg} \mathrm{~s}^{-1}$ (0.03-0.6 $\mathrm{kg} \mathrm{s}^{-1} \mathrm{~m}^{-1}$ ) (see Lenzi et al., 2004, for a more detailed description of bed-load intensities for different durations and recurrence intervals floods). From 2007 to 2011, only low small floods (up to $1.2 \mathrm{~m}^{3}$ $\mathrm{s}^{-1}$ ) were recorded with very small associated bed-load volumes (lower than $1 \mathrm{~m}^{3}$ ).

\section{Bed-load transport dynamics in the Rio Cordon}

Frequency analysis of flood events: peak discharge and bed-load volume

In order to evaluate their frequency of occurrence, the return interval of each flood was estimated from values of annual maximum instantaneous water discharge over the 25-year period, selecting for each year the largest event in case of multiple floods. Using Statistica 6.1 software (Stat Soft. Inc., Tulsa, OK, USA), the best fitting distribution and its parameters were determined. Both Gumbel and lognormal distributions were found to fit reasonably well (coefficient of KolmorovSmirnov $d=0.106$ and $d=0.156$, respectively, both indicating a non-significant difference). There is no substantial difference in recurrence intervals as calculated by the two equations (an average $\pm 8 \%$ ). The recurrence interval of the September 1994 event is around 76 years according to the lognormal distribution (Figure 2). The return intervals of bed-load volumes were also estimated using the annual maximum volumes (bulk measure). Weibull and Lognormal distributions were the best fitting (coefficient of Kolmorov-Smirnov $d=0.158$ and $d=0.161$, respectively, both indicating a non-significant difference). Again, there is no substantial difference in recurrence intervals (an average $\pm 10 \%$ ) between the two distributions. Similar to the peak water discharge analysis, the lognormal distribution is selected to calculate the recurrence intervals of bed-load volumes and the recurrence interval of bedload transport of the September 1994 flood is around 51 years according to the lognormal distribution (Figure 2).

Figure 3 shows the comparison between return intervals for water discharge and bed-load volumes. Most post-1994 points fall above the 1:1 line, whereas most pre-1994 points fall below the line. Indeed, the 1994 flood, with a peak water discharge of $10.4 \mathrm{~m}^{3} \mathrm{~s}^{-1}$ and an hourly averaged bed-load intensity of $225 \mathrm{~m}^{3} \mathrm{~h}^{-1}$, appears to represent a threshold for bed-load transport in the Rio Cordon basin. After the $14^{\text {th }}$ September 1994 flood event, a survey of sediment source areas was performed and extensive areas of reactivated sediment sources, bank erosion and several bank failures were documented along the main stream and some tributaries.

\section{Temporal trends in the bed-load transport}

The hydrological and sedimentological data of major flood events recorded in the Rio Cordon between 1986 and 2011 are presented chronologically in Figure 4, where limited and unlimited sediment supply period, separated by the September 1994 event, are highlighted. The effective runoff ( $\mathrm{Re})$, determined for each flood as the hydrograph volume exceeding the detected threshold discharges from the beginning to the end of the bed-load transport, provides a means to normalize total bed-load volumes (BL) and thus allows us to infer temporal trends in the bed-load yields. Figure 4 shows a semi-logarithmic plot of the ratio $\mathrm{BL} / \mathrm{Re}$ (with $\mathrm{Re}$ expressed as $10^{3} \mathrm{~m}^{3}$ ) for each flood. The $\mathrm{BL} / \mathrm{Re}$

Table 2. Characteristics of the floods registered at the Rio Cordon measuring station.

\begin{tabular}{|c|c|c|c|c|c|c|c|c|}
\hline Dates & Qp $\left(m^{3-1}\right)$ & RI (years) & BL $\left(\mathrm{m}^{3}\right)$ & $\mathrm{T}_{\mathrm{BL}}(\mathrm{h})$ & $\mathrm{D}_{16}(\mathrm{~mm})$ & $\mathrm{D}_{50}(\mathrm{~mm})$ & $\mathrm{D}_{84}(\mathrm{~mm})$ & $\mathrm{D}_{90}(\mathrm{~mm})$ \\
\hline 11 October 1987 & 5.15 & 5.6 & 54.8 & 8 & - & - & - & - \\
\hline 15 July 1988 & 2.43 & 1.6 & 1 & 1 & - & - & - & - \\
\hline 3 July 1989 & 4.39 & 3.9 & 85 & 27 & 54 & 103 & 207 & 242 \\
\hline 22 May 1990 & 0.85 & 1 & 1 & 1 & - & - & - & - \\
\hline 17 June 1991 & 4 & 3.3 & 39 & 20 & 30 & 51 & 100 & 135 \\
\hline 5 October 1992 & 2.91 & 2 & 9.3 & 10 & 22 & 43 & 111 & 162 \\
\hline 2 October 1993 & 4.28 & 3.7 & 13.7 & 6 & 29 & 61 & 135 & 186 \\
\hline 18 May 1994 & 1.79 & 1.2 & 1 & 12 & 21 & 33 & 52 & 62 \\
\hline 14 September 1994 & 10.42 & 52.6 & 900 & 4 & 65 & 116 & 226 & 281 \\
\hline 13 August 1995 & 2.72 & 1.8 & 6.2 & 1 & - & - & - & - \\
\hline 16 October 1996 & 2.96 & 2 & 57 & 15 & 40 & 79 & 143 & 163 \\
\hline 27 June 1997 & 1.46 & 1.1 & 1 & 1 & - & - & - & - \\
\hline 7 October 1998 & 4.73 & 4.6 & 300 & 17 & 40 & 78 & 157 & 188 \\
\hline 20 September 1999 & 3.65 & 2.8 & 19.2 & 6.4 & 32 & 54 & 98 & 117 \\
\hline 13 October 2000 & 3.28 & 2.3 & 55.6 & 35 & 39 & 61 & 111 & 123 \\
\hline 11 May 2001 & 1.46 & 1.1 & 80 & 13 & 33 & 48 & 69 & 77 \\
\hline 20 July 2001 & 1.98 & 1.4 & 20.9 & 4.7 & - & - & - & - \\
\hline May 2002 & 2.29 & 1.5 & 27.4 & 20 & 39 & 59 & 99 & 119 \\
\hline 16 November 2002 & 2.35 & 1.5 & 10 & 14.5 & - & - & - & - \\
\hline 27 November 2002 & 2.77 & 1.9 & 69.1 & 30 & 26 & 44 & 78 & 89 \\
\hline 3 May 2003 & 1.02 & 1 & 1 & 1 & - & - & - & - \\
\hline 12 June 2004 & 2.22 & 1.5 & 4.6 & - & 25 & 38 & 62 & 77 \\
\hline 6 October 2005 & 1.68 & 1.2 & 0.9 & - & 18 & 30 & 55 & 71 \\
\hline 19 May 2006 & 1.28 & 1.1 & 0.7 & - & - & - & - & - \\
\hline
\end{tabular}

Qp, peak flood discharge; RI, peak discharge return interval; BL, bedload volume (bulk measure); TBL, duration of bed-load transport; $\mathrm{D}_{16,50.89 .90}$ grain sizes for which $16 \%, 50 \%, 84 \%$ and $90 \%$, respectively, of the transported sediments are finer (Mao and Lenzi, 2007). 
ratio exhibits two decreasing trends over the 1986-1993 and 1995-2011 periods, and the BL/Re ratio of the September 1994 flood is 1 order larger than the other floods, except for the May 2001 event. During the 1994 extreme event, the channel bed was the main source of sediment for bed-load transport (Lenzi et al., 2003a, 2004), mainly because such a large discharge was able to destroy the streambed armor layer formed over the years. Also, during the September 1994 flood, old sediment sources were reactivated and new ones were created. Fine and medium size sediments eroded from the hill slope were stored in the stream network as the flood waned and were subsequently removed and transported downstream by ordinary floods in 1996, 1998 and 2000.

Similarly, almost unlimited sediment supply conditions occurred in the Rio Cordon as a consequence of the 2001 mudflow. Besides the high bed-load transport of the May 2011 event, it is estimated the small July 2001 flood mobilized $21 \mathrm{~m}^{3}$ of bed-load material from the newly formed fan. The three floods in 2002 also show high sediment loads and this may be partly an inheritance of the May 2001 mudflow, and the area close to the measuring station during the November 2002 event might have contributed considerably to the high bed-load transport of this flood.

A

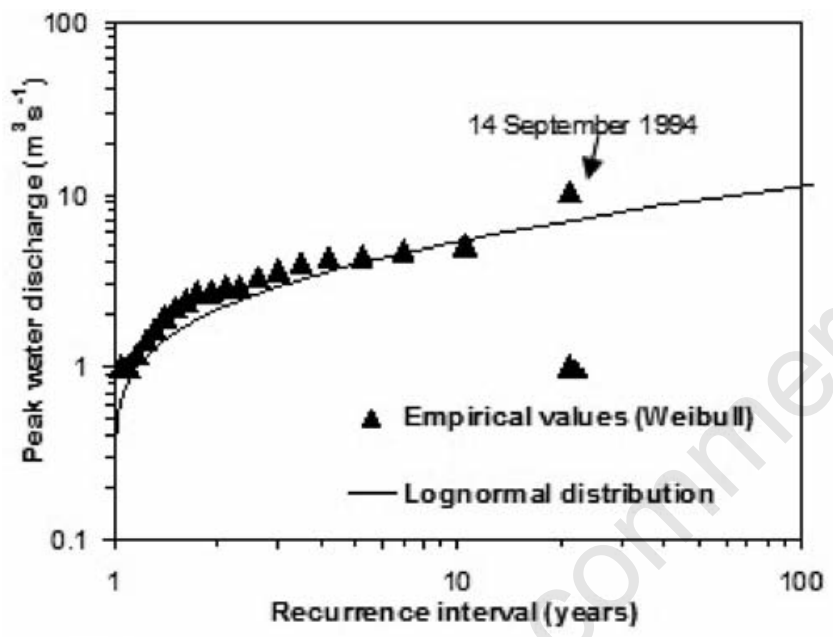

B

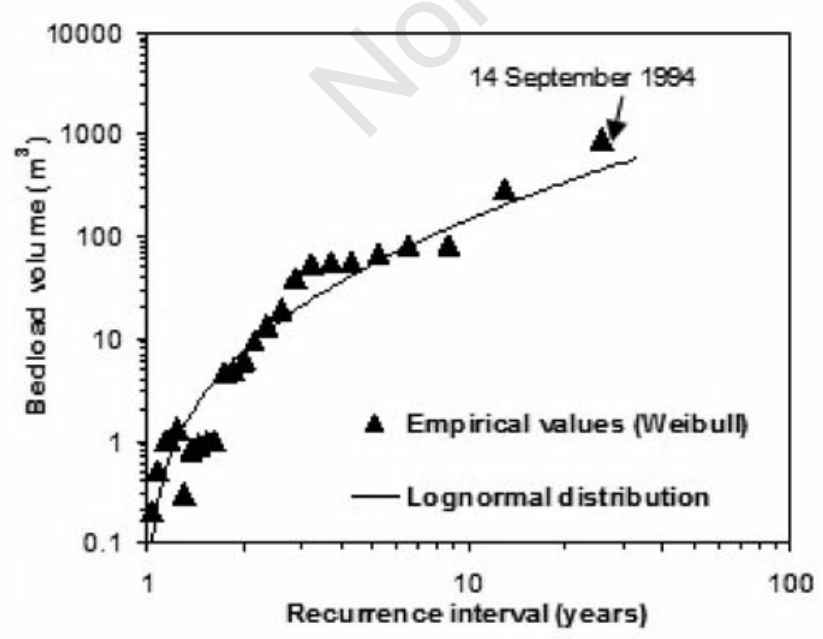

Figure 2. (A) magnitude-frequency relationship for annual maximum peak discharge and $(B)$ magnitude-frequency relationship for annual maximum bed load volume. The bed-load volumes are expressed as bulk measure (including voids).
Travel length of marked bed particles

From field observations carried out on the displacement length of various sizes of $\left(32<\mathrm{d}_{\mathrm{i}}<512 \mathrm{~mm}\right)$ bed particles during individual flood events in the 1993-1994 and 1996-1998 periods, it was observed that the total displacement length $\left(l_{i}\right)$ depends on the degree of mobilization of the individual fractions of the bed surface. $l_{i}$ is independent of $\mathrm{d}_{\mathrm{i}}$ for smaller, fully mobile grain sizes and decreases rapidly with Di for larger fractions in a state of partial transport (Lenzi, 2004). Sustained selective transport without a supply of sediment from upstream leads to the development of a stable coarse armored surface through progressive winnowing of finer material from the bed surface. With unlimited supply conditions for transport, both the occurrence of extreme events and the duration of a sequence of ordinary floods play an important role in the degree of mobilization of the individual fractions of the bed (Lenzi, 2004).

Near equimobility conditions from pebbles to small boulders (32-256 $\mathrm{mm}$ i.e., up to the $\mathrm{d}_{76}$ of the bed surface grain size distribution) were established for the 1994 event $\left(Q p=10.4 \mathrm{~m}^{3} \mathrm{~s}^{-1}\right.$, R.I. around 51 years) while selective entrainment occurred for larger clast size (up to 512

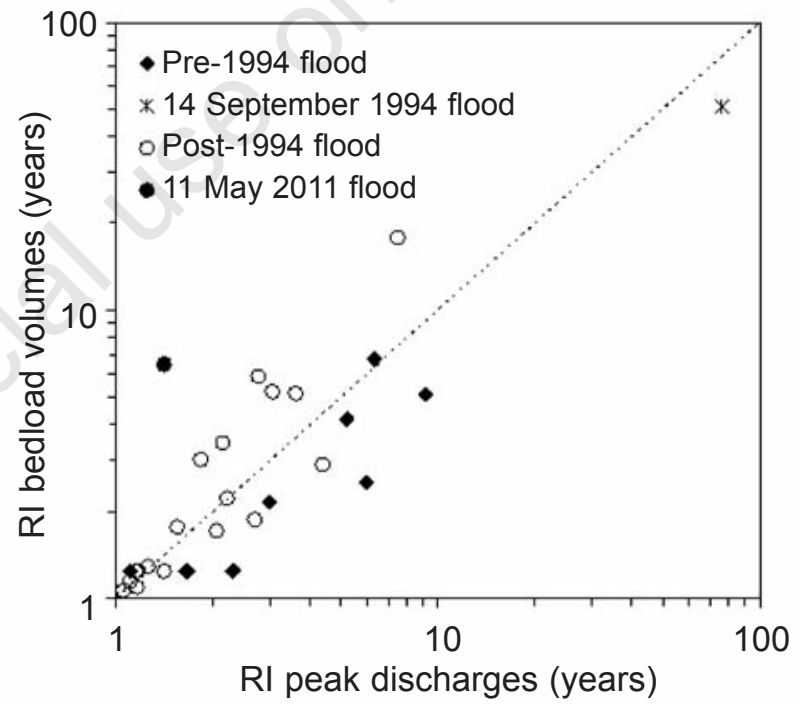

Figure 3. Comparison of recurrence intervals referring to liquid peak discharge and total bed-load volumes for each recorded flood event.

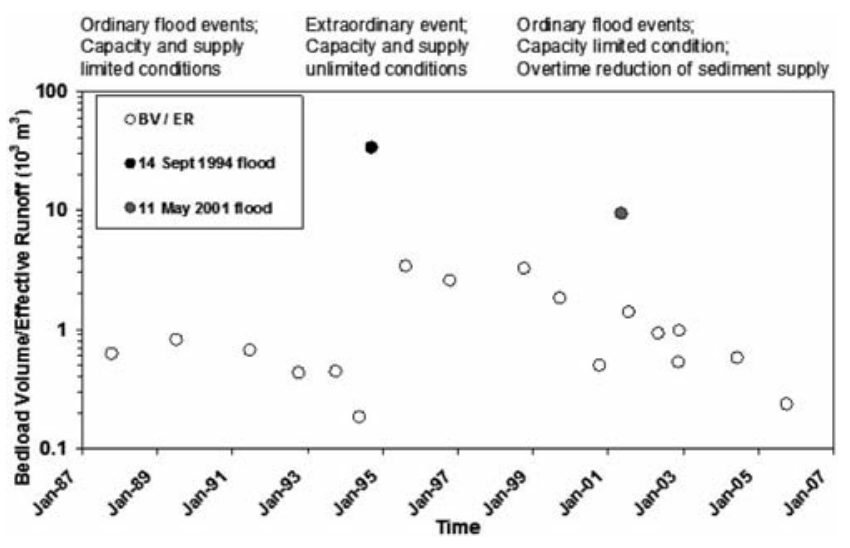

Figure 4. The ratio bed-load volume/effective runoff over the 25 years of records. 
$\mathrm{mm}$ ). This might indicate that, during this event, a transport stage between a well-developed Phase II and the beginning of Phase III transport (Ashworth and Ferguson, 1989; Warburton, 1992) was reached. This hypothesis is supported by the findings of Lenzi et al. (2004), who highlighted that the very high bed-load rates of the September 1994 flood are much higher than the second largest event (the 1998 flood, $Q p=4.7 \mathrm{~m}^{3} \mathrm{~s}^{-1}$, R.I. about 5 years; equimobility only for size classes up to the $d_{40}$ ).

\section{Effective discharges}

The availability of hourly values of bed-load transport in the Rio Cordon for a very large range of water discharges made it possible to use both the traditional bed-load rating curve approach and the actual bed-load transport rates for each flow class, using the average values (Mao et al., 2005). The effective discharge provided by the traditional Wolman and Miller (1960) approach, involving the use of a power sediment rating curve and a lognormal flow frequency curve, can be considered first. The product of the two curves starts at $1.4 \mathrm{~m}^{3} \mathrm{~s}^{-1}$, which is the minimum value for the application of the rating curve, and reaches its peak at a water discharge of $2.45 \mathrm{~m}^{3} \mathrm{~s}^{-1}$. This value (R.I. $=1.72$ year, equaled or exceeded for an average $7 \mathrm{~h}$ per year or $0.02 \%$ of the time), therefore, represents the bed-load effective discharge, and is very close to the estimated bank full discharge of $2.3 \mathrm{~m}^{3} \mathrm{~s}^{-1}$. Using the measured bed-load transport rates and the empirical flow frequencies, grouped in classes of $0.1 \mathrm{~m}^{3} \mathrm{~s}^{-1}$, the effective discharge distribution turns out to be much more irregular and to have a very uneven pattern that prevents the identification of a representative peak. The actual maximum occurs at $\mathrm{Q}=2.65 \mathrm{~m}^{3} \mathrm{~s}^{-1}$, similar to the previously obtained $2.45 \mathrm{~m}^{3} \mathrm{~s}^{-1}$. Nevertheless, three other high values, very close to the absolute maximum, are reached at $1.65,3.45$ and $3.95 \mathrm{~m}^{3} \mathrm{~s}^{-1}$, thus questioning the appropriateness of a unique effective discharge. As pointed out by Crowder and Knapp (2005), the evaluation of the effective discharge is significantly influenced by the kind of sediment data used (i.e. rating curve $v s$ empirical data). The type of flow frequency curve (empirical $v$ s fitted distribution) and its class intervals also affect the effective discharge determination.

\section{Total sediment yield}

The two turbidimeters collect measurements every 5 min during flood times; in order to calculate the daily values of suspended solid load needed for working out annual budgets, an empirical correlation between water discharge and suspended sediment concentration was used to cover periods characterized by flows lower than a certain discharge threshold (i.e., $0.8 \mathrm{~m}^{3} \mathrm{~s}^{-1}$ ). Different relationships were obtained for summer-autumn floods and for spring snowmelt runoff. Analyzing the annual budgets of the suspended solid transport for the whole period, it appears that $76 \%$ of the total sediment load which occurred over the whole period was in the form of suspended transport; this rate decreases to $64 \%$ if calculated considering only the flood events.

However, most of this volume was supplied during only two single floods: September 1994 and May 2001, with 27\% and 11\%, respectively (Lenzi et al., 2003b). Such a result confirms the strong link between suspended load and the availability of sediment sources. During the first part of the $14^{\text {th }}$ September 1994 hydrograph event, suspended transport was the dominant process, in contrast to the second part, when suspended sediment was still important but the massive water discharge led to very large bed-load rates. Overall, suspended load accounts for approximately $61 \%$ by weight of the total sediment yield. In fact, as for reports considering bed-load transport, suspended sediment yield are essentially conditioned by this extreme event, and post1994 average annual suspended load is higher than for the preceding events.

Averaging the 18 years of data, the mean annual specific sediment yield is $146.8 \mathrm{t} \mathrm{km}^{-2}$ year-1. However, it must be pointed out that this includes the 1986-1993 period characterized by ordinary floods during which the mean sediment production was $77.7 \mathrm{t} \mathrm{km}^{-2}$ year-1, the massive sediment yield in $1994\left(813.0 \mathrm{t} \mathrm{km}^{-2}\right.$ year-1 $\left.^{-1}\right)$ and, finally, the post1994 period featuring high annual loads $\left(130.6 \mathrm{t} \mathrm{km}^{-2}\right.$ year-1 $\left.^{-1}\right)$. The proposed interpretation is that high-magnitude, low-frequency flows reactivating or creating new sediment sources have a direct effect on sediment supply conditions and can then substantially increase the amount of sediment transported by subsequent floods. Once the streambed equilibrium has been dramatically altered, many years may be needed before new bed stability is achieved (Lenzi et al., 2003b).

\section{Conclusions}

This summary emphasizes the crucial connection between channel processes and sediment sources in mountain rivers. The key issue is the degree to which hill slopes and stream channel are coupled along with the stability of bed armoring, both of which significantly depend on the recurrence interval of flood events. In small mountain basins, the channel may remain decoupled and armored for many years, until a low-frequency, high-magnitude event (such as the 1994 flood in the Rio Cordon) removes the coarse surface layer, abruptly increasing sediment supply, and thus leads to higher sediment transport rates and mean annual yields.

Although the station has overall fulfilled its required tasks, there are several aspects that could be improved to allow more accurate bed -oad measurements to be taken. For example:

- a simple shielding structure over and beside the ultrasonic sensors would avoid swinging and protect them from adverse weather conditions;

the roof above the storage area could be an appropriate location for a fixed video camera and a spotlight in order to continuously record the formation of the sediment mound;

- coating the bottom of the bed-load storage area would permit more precise ultrasonic measurements and a simpler post-flood bed load removal;

- in order to increase the accuracy of discharge measurements during high flows, the inlet channel upstream of the station should be extended for approximately $5 \mathrm{~m}$ to avoid the formation of standing waves disturbing the flow gauging system.

The Rio Cordon measuring facility has provided excellent data and a valuable insight into the bed-load dynamics of steep streams throughout its 25 years of operations, thanks to the close collaboration between the Arabba Avalanche Center (Veneto Region) and the Department of Land and Agro-Forest Environment (University of Padua). However, the maintenance costs of the station are not low and these may have an impact on its future operations. Improving the current instrumentation and installation with novel technology would make the station an ideal location for calibrating surrogate techniques for bed-load monitoring.

\section{References}

Andreoli A., Comiti F., Lenzi M.A. 2005. [Natural step-pools are analogous to pools formed below grade-control works]. Rivista di Ingegneria Agraria 3:1-13. [In Italian].

Asworth P.J., Ferguson R.I. 1989. Size-selective entrainment of bedload in gravelbed stream. Water Resour. Res. 25:627-34.

Bathurst J.C., Crosta G.B., Garcìa-Ruiz J.M., Guzzetti F., Lenzi M.A. Araguès S.R. 2003. DAMOCLES: Debris-fall assessment in mountain catchments for local end-users. Int. Conf. Debris-Flow Hazards 
Mitigation: Mechanics, Prediction and Assessment, edited by D. Rickenmann and C. Chen, Millpress, Rotterdam, pp. 1073-83.

Bathurst J.C., Amezaga J., Cisneros F., Gavino-Novillo M., Iroumè A., Lenzi M.A., Mintegui Aguirre J.A., Urciuolo A. 2010. Forest and floods in Latin America: Science, management, policy and the EPIC FORCE project. Water Int. 35:114-31.

Bischetti G., Chiaradia E.A. 2010. Calibration of distributed shallow landslide models in forested landscapes. J. Agricult. Engineer. 4:2335.

Crowder D.W., Knapp H.V. 2005. Effective discharge recurrence intervals of Illinois streams. Geomorphology 64:167-85.

Dalla Fontana, G. Marchi L. 2003. Slope-area relationships and sediment dynamics in two alpine streams. Hydrol. Processes 17:73-87.

Di Stefano C., Di Piazza G.V., Ferro V. 2007. Field testing of SMBF flume. J. Agricult. Engineer. 4:37-44.

Fattorelli S., Keller H.M., Lenzi M.A., Marchi L. 1988. An experimental station for the automatic recording of water and sediment discharge in a small alpine watershed. Hydrol. Sci. J. 33:607-17.

Lenzi M.A. 2001. Step-pool evolution in the Rio Cordon, Northeastern Italy. Earth Surf. Processes Landforms 26:991-1008.

Lenzi M.A. 2004. Displacement and transport of marked pebbles, cobbles and boulders during flood in a steep mountain stream. Hydrol. Processes 18:1899-914.

Lenzi M.A. 2006. Research developments in debris flow monitoring, modeling and hazard assessment in Italian mountain catchments. WIT Trans. Ecol. Environ. 90:135-45.

Lenzi M.A., Marchi L. 2000. Suspended sediment load during floods in a small stream of the Dolomites (northeastern Italy). Catena 39:267-82.

Lenzi M.A., Marchi L., Scussel G.R. 1990. Measurement of coarse sediment transport in a small alpine stream. In: Lang H., Musy A., eds. International Conference on Water Resources in Mountainous Regions, Lausanne, Switzerland, 27 August-1 September 1990. International Association of Hydrological Sciences. IAHS/AISH Publication no. 193:283-290.

Lenzi M.A., D’Agostino V., Billi P. 1999. Bedload transport in the instrumented catchment of the Rio Cordon: Part I. Analysis of bedload records, conditions and threshold of bedload entrainment. Catena 36:171-90.

Lenzi M.A., D’Agostino V., Gregoretti C., Sonda D. 2003a. A simplified numerical model for debris flow hazard assessment: DEFLIMO. Int. Conf. Debris-Flow Hazards Mitigation: Mechanics, Prediction and Assessment, Proc., Davos, Switzerland, 1:611-22.

Lenzi M.A., Mao L., Comiti F., 2003b. Interannual variation of sediment yield in an alpine catchment. Hydrol. Sci. J. 48:899-915.

Lenzi M.A., Mao L., Comiti F. 2004. Magnitude-frequency analysis of bed load data in an Alpine boulder bed stream. Water Resour. Res. 40:W07201.

Lenzi M.A., Mao L., Comiti F. 2006. When does bedload transport begin in steep boulder-bed streams? Hydrol. Processes 20:3517-33.

Lenzi M.A., Mao L., Cavalli M. 2011. Long term monitoring of bedload and debris flows in two small basins of different morphological settings. Int. Conf. Debris-Flow Hazards Mitigation: Mechanics, Prediction and Assessment, Proc., Padova, Italy, 1: 573-581.

Mao L., Comiti F., Andreoli A., Lenzi M.A., Scussel G.R. 2005. Bankfull and bed load effective discharge in a steep boulder-bed channel. In: Walling D.E., Horowitz A.J., eds. Sediment budget I. IAHS Publication no. 291:189-95.

Mao L., Lenzi M.A. 2007. Sediment mobility and bedload transport conditions in an alpine stream. Hydrol. Processes 21:1882-91.

Mao L., Uyttendaele G.P., Iroumé A., Lenzi M.A. 2008. Field based analysis of sediment entrainment in two high gradient streams located in Alpine and Andine environments. Geomorphology 93:368-83.

Mao L., Cavalli M., Comiti F., Marchi L., Lenzi M.A., Arattano M. 2009. Sediment transfer processes in two Alpine catchments of contrasting morphological settings. J. Hydrol. 364:88-98.

Mintegui Aguirre J.A., Robredo Sanchez J.C., Mao L., Lenzi M.A. 2010. Formation, expantion and restoration of a sedimentation fan: the case of the Arroyo del Partido stream (Spain). WIT Trans. Eng. Sci. 67:249-59.

Niedda M., Greppi M. 2010. Watershed runoff and river flow modeling in land use planning. J. Agricult. Engineer. 2:20-8.

Nitsche M., Rickenmann D., Turowski J.M., Badoux A., Kirchner J.M. 2011. Evaluation of bedload transport using flow resistance equations to account for macro-roughness in steep mountain streams. Water Resour. Res. 47:W08513.

Powell M.P., Reid I., Laronne J.B. 2000. Evolution of bed load distribution with increasing flow strength and the effect of flow duration on the caliber of bed load sediment yield in ephemeral gravel bed rivers. Water Resour. Res. 37:1463-74.

Rigon E., Comiti F., Lenzi M.A. 2012. Large wood storage in streams of the Eastern Italian Alps and the relevance of hillslope processes. Water Resour. Res. 48:W01518.

Warburton J. 1992. Observations of bed load transport and channel bed changes in a proglacial mountain stream. Arct. Alp. Res. 24:195-203.

Wohl E.E. 2000. Mountain Rivers. Water Resources Monograph no. 14, Washington, DC, USA.

Wolman M.G., Miller J.P. 1960. Magnitude and frequency of forces in geomorphic processes. J. Geol. 68:54-74.

Yager E.M., Dietrich W.E., Kirchner J.M., McArdell B.W. 2012. Prediction of sediment transport in steep pool channels. Water Resour. Res. 48:W01541. 